\title{
DESIGN OF THE CEILING ASSISTANCE
}

\section{Sandi Yusuf Heri Wibowo, Darto*, I Made Sunada}

Department of Mechanical Engineering, Faculty of Engineering, University of Merdeka Malang

*Email corresponding author: darto@unmer.ac.id

\begin{abstract}
Ceiling installation auxiliary tool is auxiliary tool for installing a ceiling with a simple method. Namely by placing the ceiling above the cross section and moving the gears to the ceiling can reach the desired height. This auxiliary tool is needed to help to lighten the workload and save the ceiling installation time. This auxiliary tool can reach places or rooms that have narrow access, because this tool can be dismantled pairs. This tool can hold the user load up to $80 \mathrm{~kg}$ and the weight of the ceiling up to $47.3 \mathrm{~kg}$, so the total weight reached $127.3 \mathrm{~kg}$. This auxiliary tool has four pedestal wheels that can move as desired.
\end{abstract}

Keywords: Design auxiliary tool, hollow iron size, joint

\section{INTRODUCTION}

The construction of subsidized houses is the government's effort to meet the needs of the underprivileged by building BTN housing. Rumah BTN with a total area of $10 \times 6$ meters has room sizes ranging from 1.5 square meters to $3.5 \times 4$ meters, so the distance between the floor and the ceiling (ceiling) is determined from the area of the room. For the ceiling installed on BTN housing, many of them use plasterboard material with a size of 1 square meter because the price is cheap and the installation is not so complicated, it can be done by 1 worker (Safitri, 2011).

Therefore a ceiling installation tool was designed so that it can help lighten and speed up the work of installing the ceiling, where usually the work for installing the ceiling tends to use wooden beam supports or holding the ceiling by hand and the time needed for 1 ceiling installation takes about
9 minutes to do. by 1 worker. With limited workers, it is hoped that with this tool the energy and time needed is more efficient.

This ceiling fixing tool has a simple construction and design. This ceiling installation tool does not use sophisticated equipment and very complicated computer programs. so that the users of this tool can operate easily, for the construction materials of this tool use materials that are easy to find and have good quality, where the raw materials determine the quality of the tools and the quality of good materials greatly affects the age and strength of the tools.

\section{Research Question}

1) How to design a simple ceiling installation tool that is easy to operate and details the design ratio.

2) How to produce ceiling installation tools with theoretical calculations 
based on factors of strength, safety, design, and other supporting factors.

3) How to make a detailed design for ceiling installation tools.

\section{Limitation of Problem}

The problem limits in this final project are:

1) The initial height of the tool is 170 $\mathrm{cm}$.

2) Installation for a ceiling size of $1 \mathrm{~m} \mathrm{x}$ $1 \mathrm{~m}$.

3) Ceiling installation using ceiling screws.

\section{Research Objective}

The purpose of designing the ceiling installation tool is as follows:

1) Draw ceiling support aid ratio.

2) Designing ceiling fixing tools.

3) Describes the function of the ceiling fixing aid.

4) Calculating the theoretical design.

\section{METHODOLOGY}

\section{Material Used}

1. Hollow Iron

2. Iron pipe

3. Bearings

4. Wheels

5. Ring Bolts

6. Gears

\section{Ceiling Specifications}

The size of the ceiling is in accordance with the specifications of the assistive device, namely $1 \mathrm{~m}$ length, $1 \mathrm{~m}$ width, and $3 \mathrm{~mm}$ thick with a weight of $4.3 \mathrm{~kg}$.

Table1 Kalsiboard Ceiling Size

\begin{tabular}{|r|c|c|c|}
\hline $\begin{array}{c}\text { Tebal } \\
(\mathrm{mm})\end{array}$ & $\begin{array}{c}\text { Lebar } \\
(\mathrm{mm})\end{array}$ & $\begin{array}{c}\text { Panjang } \\
(\mathrm{mm})\end{array}$ & $\begin{array}{c}\text { Berat } \\
(\mathrm{kg})\end{array}$ \\
\hline+3.0 & 1000 & 1000 & 4.3 \\
\hline 3.0 & 500 & 1000 & 2.2 \\
\hline 3.0 & 1000 & 2000 & 8.6 \\
\hline 3.0 & 500 & 2000 & 4.3 \\
\hline
\end{tabular}

\section{Research Flowchart}

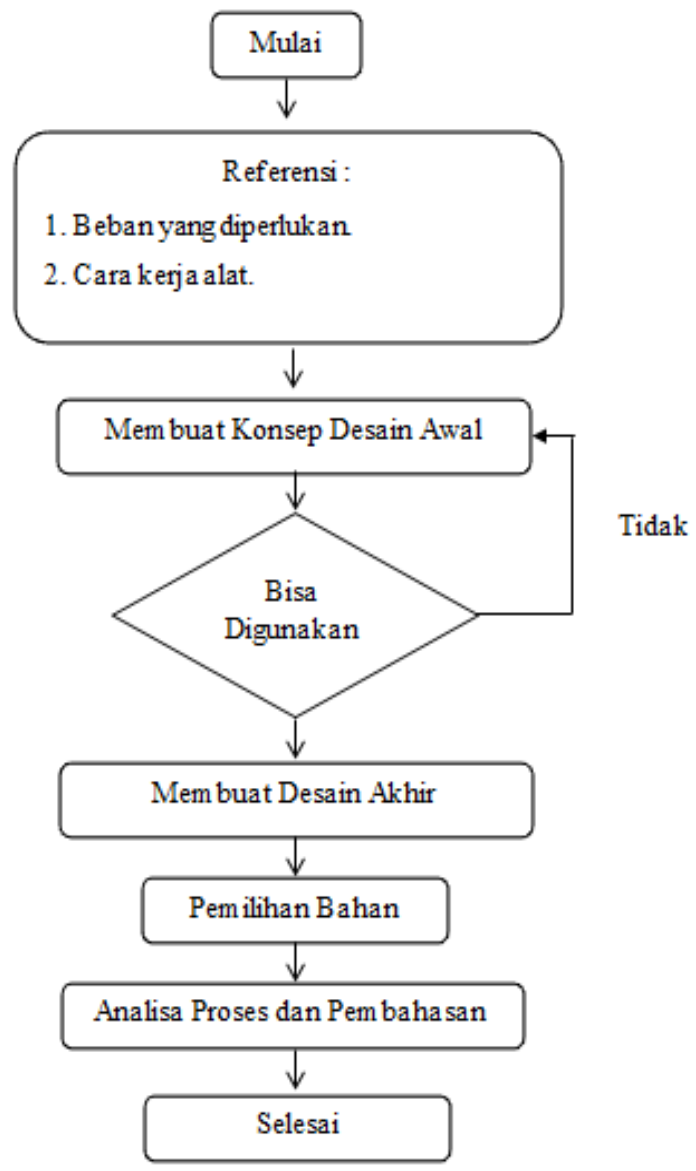

\section{Hollow Iron Specifications}

For the auxiliary framework in planning this tool using Hollow Iron with a 
height of $4 \mathrm{~cm}, 4 \mathrm{~cm}$ wide, and $2 \mathrm{~mm}$ thick. For the main frame using Hollow Iron with a size of $5 \mathrm{~cm}$ high, $5 \mathrm{~cm}$ wide, and $2 \mathrm{~mm}$ thick.

Table 2 Standard Size of Hollow Iron

\begin{tabular}{|c|c|c|c|c|c|c|c|}
\hline \multicolumn{8}{|c|}{ STANDAR UKURAN BESI HOLLOW } \\
\hline Tinggi & Lebar & Tebal & Panjang & Tinggi & Lebar & Tebal & Panjang \\
\hline $1,5 \mathrm{~cm} \times$ & $3 \mathrm{~cm}$ & $0,6 \mathrm{~mm}$ & $6 \mathrm{~m}$ & $3 \mathrm{~cm} x$ & $3 \mathrm{~cm}$ & $1,7 \mathrm{~mm}$ & $6 \mathrm{~m}$ \\
\hline $1,5 \mathrm{~cm} \times$ & $3 \mathrm{~cm}$ & $0,8 \mathrm{~mm}$ & $6 \mathrm{~m}$ & $3 \mathrm{~cm} x$ & $3 \mathrm{~cm}$ & $2 \mathrm{~mm}$ & $6 \mathrm{~m}$ \\
\hline $1,5 \mathrm{~cm} \times$ & $3 \mathrm{~cm}$ & $1,1 \mathrm{~mm}$ & $6 \mathrm{~m}$ & $3 \mathrm{~cm} \times$ & $6 \mathrm{~cm}$ & $0,8 \mathrm{~mm}$ & $6 \mathrm{~m}$ \\
\hline $1,5 \mathrm{~cm} \times$ & $3 \mathrm{~cm}$ & $1,4 \mathrm{~mm}$ & $6 \mathrm{~m}$ & $3 \mathrm{~cm} x$ & $6 \mathrm{~cm}$ & $1,1 \mathrm{~mm}$ & $6 \mathrm{~m}$ \\
\hline $1,7 \mathrm{~cm} \times$ & $3,7 \mathrm{~cm}$ & $0,6 \mathrm{~mm}$ & $6 \mathrm{~m}$ & $3 \mathrm{~cm} x$ & $6 \mathrm{~cm}$ & $1,4 \mathrm{~mm}$ & $6 \mathrm{~m}$ \\
\hline $1,7 \mathrm{~cm} \times$ & $3,7 \mathrm{~cm}$ & $1,1 \mathrm{~mm}$ & $6 \mathrm{~m}$ & $3 \mathrm{~cm} x$ & $6 \mathrm{~cm}$ & $1,7 \mathrm{~mm}$ & $6 \mathrm{~m}$ \\
\hline $1,7 \mathrm{~cm} \times$ & $3,7 \mathrm{~cm}$ & $1,4 \mathrm{~mm}$ & $6 \mathrm{~m}$ & $3,7 \mathrm{~cm} \times$ & $3,7 \mathrm{~cm}$ & $0,6 \mathrm{~mm}$ & $6 \mathrm{~m}$ \\
\hline $1,7 \mathrm{~cm} \times$ & $3,7 \mathrm{~cm}$ & $1,7 \mathrm{~mm}$ & $6 \mathrm{~m}$ & $3,7 \mathrm{~cm} \times$ & $3,7 \mathrm{~cm}$ & $0,8 \mathrm{~mm}$ & $6 \mathrm{~m}$ \\
\hline $2 \mathrm{~cm} \times$ & $2 \mathrm{~cm}$ & $0,6 \mathrm{~mm}$ & $6 \mathrm{~m}$ & $3,7 \mathrm{~cm} \times$ & $3,7 \mathrm{~cm}$ & $1,1 \mathrm{~mm}$ & $6 \mathrm{~m}$ \\
\hline $2 \mathrm{~cm} x$ & $2 \mathrm{~cm}$ & $1,1 \mathrm{~mm}$ & $6 \mathrm{~m}$ & $3,7 \mathrm{~cm} \times$ & $3,7 \mathrm{~cm}$ & $1,4 \mathrm{~mm}$ & $6 \mathrm{~m}$ \\
\hline $2 \mathrm{~cm} x$ & $2 \mathrm{~cm}$ & $1,4 \mathrm{~mm}$ & $6 \mathrm{~m}$ & $3,7 \mathrm{~cm} \times$ & $3,7 \mathrm{~cm}$ & $1,7 \mathrm{~mm}$ & $6 \mathrm{~m}$ \\
\hline $2 \mathrm{~cm} x$ & $2 \mathrm{~cm}$ & $1,7 \mathrm{~mm}$ & $6 \mathrm{~m}$ & $4 \mathrm{~cm} \mathrm{x}$ & $4 \mathrm{~cm}$ & $0,8 \mathrm{~mm}$ & $6 \mathrm{~m}$ \\
\hline $2 \mathrm{~cm} \times$ & $4 \mathrm{~cm}$ & $0,6 \mathrm{~mm}$ & $6 \mathrm{~m}$ & $4 \mathrm{~cm} x$ & $4 \mathrm{~cm}$ & $1,1 \mathrm{~mm}$ & $6 \mathrm{~m}$ \\
\hline $2 \mathrm{~cm} \times$ & $4 \mathrm{~cm}$ & $0,8 \mathrm{~mm}$ & $6 \mathrm{~m}$ & $4 \mathrm{~cm} \times$ & $4 \mathrm{~cm}$ & $1,4 \mathrm{~mm}$ & $6 \mathrm{~m}$ \\
\hline $2 \mathrm{~cm} x$ & $4 \mathrm{~cm}$ & $1,1 \mathrm{~mm}$ & $6 \mathrm{~m}$ & $4 \mathrm{~cm} x$ & $4 \mathrm{~cm}$ & $1,7 \mathrm{~mm}$ & $6 \mathrm{~m}$ \\
\hline $2 \mathrm{~cm} \mathrm{x}$ & $4 \mathrm{~cm}$ & $1,4 \mathrm{~mm}$ & $6 \mathrm{~m}$ & $4 \mathrm{~cm} \mathrm{x}$ & $4 \mathrm{~cm}$ & $2 \mathrm{~mm}$ & $6 \mathrm{~m}$ \\
\hline $2 \mathrm{~cm} \mathrm{x}$ & $4 \mathrm{~cm}$ & $1,7 \mathrm{~mm}$ & $6 \mathrm{~m}$ & $4 \mathrm{~cm} \mathrm{x}$ & $6 \mathrm{~cm}$ & $0,6 \mathrm{~mm}$ & $6 \mathrm{~m}$ \\
\hline $2 \mathrm{~cm} x$ & $4 \mathrm{~cm}$ & $2 \mathrm{~mm}$ & $6 \mathrm{~m}$ & $4 \mathrm{~cm} x$ & $6 \mathrm{~cm}$ & $0,1 \mathrm{~mm}$ & $6 \mathrm{~m}$ \\
\hline $2,5 \mathrm{~cm} \times$ & $5 \mathrm{~cm}$ & $0,8 \mathrm{~mm}$ & $6 \mathrm{~m}$ & $4 \mathrm{~cm} \times$ & $6 \mathrm{~cm}$ & $1,4 \mathrm{~mm}$ & $6 \mathrm{~m}$ \\
\hline $2,5 \mathrm{~cm} \times$ & $5 \mathrm{~cm}$ & $1,1 \mathrm{~mm}$ & $6 \mathrm{~m}$ & $4 \mathrm{~cm} \mathrm{x}$ & $6 \mathrm{~cm}$ & $1,7 \mathrm{~mm}$ & $6 \mathrm{~m}$ \\
\hline $2,5 \mathrm{~cm} \mathrm{x}$ & $5 \mathrm{~cm}$ & $1,4 \mathrm{~mm}$ & $6 \mathrm{~m}$ & $4 \mathrm{~cm} \times$ & $6 \mathrm{~cm}$ & $2 \mathrm{~mm}$ & $6 \mathrm{~m}$ \\
\hline $2,5 \mathrm{~cm} \times$ & $5 \mathrm{~cm}$ & $1,7 \mathrm{~mm}$ & $6 \mathrm{~m}$ & $5 \mathrm{~cm} \times$ & $5 \mathrm{~cm}$ & $1,1 \mathrm{~mm}$ & $6 \mathrm{~m}$ \\
\hline $3 \mathrm{~cm} x$ & $5 \mathrm{~cm}$ & $0,6 \mathrm{~mm}$ & $6 \mathrm{~m}$ & $5 \mathrm{~cm} \times$ & $5 \mathrm{~cm}$ & $1,4 \mathrm{~mm}$ & $6 \mathrm{~m}$ \\
\hline $3 \mathrm{~cm} \mathrm{x}$ & $3 \mathrm{~cm}$ & $0,8 \mathrm{~mm}$ & $6 \mathrm{~m}$ & $5 \mathrm{~cm} \times$ & $5 \mathrm{~cm}$ & $1,7 \mathrm{~mm}$ & $6 \mathrm{~m}$ \\
\hline $3 \mathrm{~cm} x$ & $3 \mathrm{~cm}$ & $1,1 \mathrm{~mm}$ & $6 \mathrm{~m}$ & $5 \mathrm{~cm} \times$ & $5 \mathrm{~cm}$ & $2 \mathrm{~mm}$ & $6 \mathrm{~m}$ \\
\hline $3 \mathrm{~cm} x$ & $3 \mathrm{~cm}$ & $1,4 \mathrm{~mm}$ & $6 \mathrm{~m}$ & & & & \\
\hline
\end{tabular}

\section{Equipment Used To Make Ceiling}

\section{Mounting Aids}

1. Electric welding.

2. Burrs Cut.

3. Ruler/Measuring Tool.

4. Gurdi Machine.

5. Key Ring/Pas.

6. Hammer etc.

\section{Design Tools}

The design of this ceiling installation tool is expected to be able to help with ceiling installation problems, even though it is a simulation tool but its properties and processes are conditioned as phenomena that occur in general.

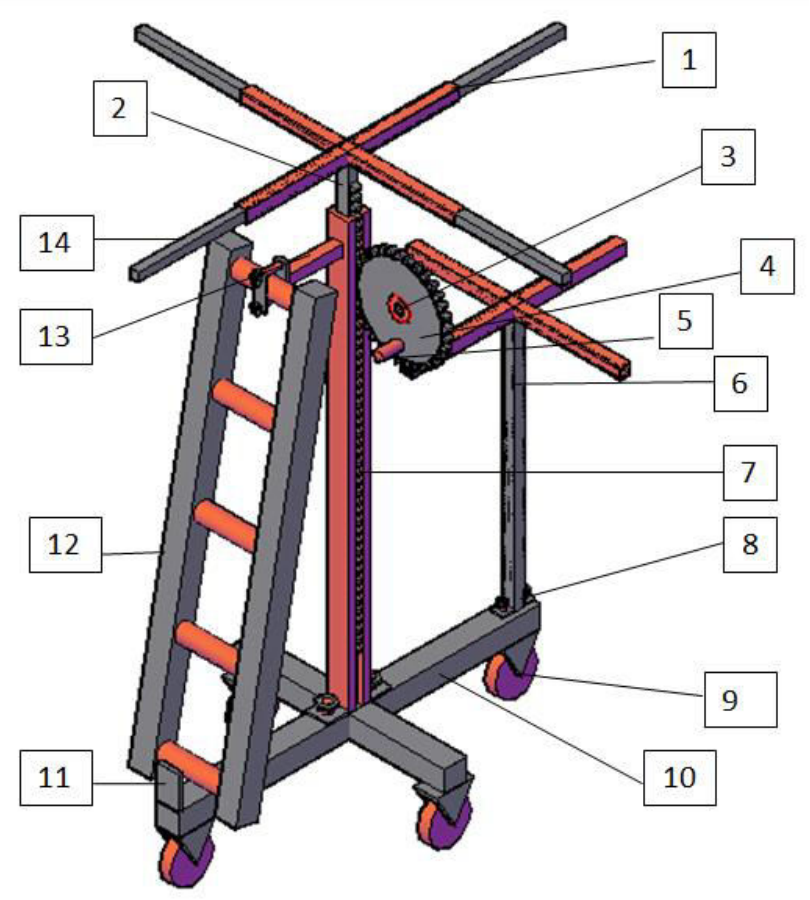

Figure 5. Ceiling Installation Tool Design 
Ceiling Mounting Tool Parts

1. Cross section

2. Main Support Pillar

3. Bearings

4. Gears

5. Gear Lever

6. Poles

7. Gear Rack

8. Nut and bolt

9. Wheels

10. Main Section

11. Ladder Retaining Plate

12. Stairs

13. Stair Holders / Stair Clamps

14. Cross Sleeve
How the Tool Works

The working principle of the ceiling fixing tool is by turning the lever in the gear clockwise, then the gear that is in contact with the rack gear automatically moves the support pole that is on the main support post. The poles are made in a telescopic model intended to save space, for the design itself it is made portable so that it can be carried wherever the user wants the tool. The wheel can only go forward and backward, this is so that the locking of the wheel is only centered on one wheel of the tool.

\section{Processing Process}

\begin{tabular}{|c|c|c|c|c|c|c|}
\hline $\mathbf{N}$ & $\begin{array}{l}\text { Design } \\
\text { Figure }\end{array}$ & Name & Materials & Process & Tools & Total \\
\hline 1 & 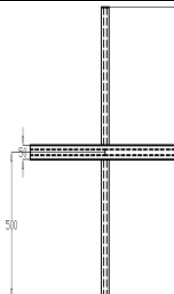 & Section & $\begin{array}{c}\text { Hollow Iron } \\
5 \mathrm{~cm} \times 5 \mathrm{~cm} \\
\text { dan } \\
4 \mathrm{~cm} \times 4 \mathrm{~cm}\end{array}$ & $\begin{array}{ll}\text { - } & \text { Cut } \\
\text { - } & \text { Weld }\end{array}$ & $\begin{array}{ll}\text { - } & \text { Burrs } \\
\text { - } & \text { Electric } \\
& \text { welding } \\
\text { - } & \text { Ruler }\end{array}$ & 2 \\
\hline 2 & $\|_{-\infty} !$ & $\begin{array}{c}\text { Main } \\
\text { Support } \\
\text { Pillar }\end{array}$ & $\begin{array}{c}\text { Hollow Iron } \\
5 \mathrm{~cm} \times 5 \mathrm{~cm} \\
\text { dan } \\
4 \mathrm{~cm} \times 4 \mathrm{~cm}\end{array}$ & $\begin{array}{ll}\text { - } & \text { Cut } \\
\text { - } & \text { Las } \\
\text { - } & \text { Clamp } \\
\text { - } & \text { Auger }\end{array}$ & $\begin{array}{ll}\text { - } & \text { Burrs } \\
\text { - } & \text { Electric } \\
& \text { welding } \\
\text { - } & \text { Ruler } \\
\text { - } & \text { Electric Drill }\end{array}$ & 1 \\
\hline 3 & 4 & Poles & $\begin{array}{l}\text { Hollow Iron } \\
4 \mathrm{~cm} \times 4 \mathrm{~cm}\end{array}$ & $\begin{array}{ll}\text { - } & \text { Cut } \\
\text { - } & \text { Las } \\
\text { - } & \text { Clamp } \\
\text { - } & \text { Auger }\end{array}$ & $\begin{array}{ll}\text { - } & \text { Burrs } \\
\text { - } & \text { Electric } \\
& \text { welding } \\
\text { - } & \text { Ruler }\end{array}$ & 2 \\
\hline
\end{tabular}




\begin{tabular}{|c|c|c|c|c|c|c|}
\hline & & & & & - Electric Drill & \\
\hline 4 & 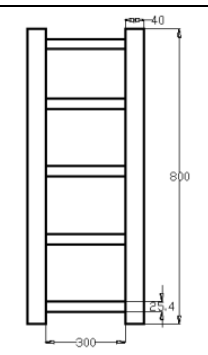 & Ladder & $\begin{array}{c}\text { Hollow Iron } \\
4 \mathrm{~cm} \times 4 \mathrm{~cm} \\
\text { Dan } \\
\text { Pipa Besi } \\
2,54 \mathrm{~cm}\end{array}$ & $\begin{array}{ll}\text { - } & \text { Cut } \\
\text { - Weld } & \text { Wel }\end{array}$ & $\begin{array}{ll}\text { - } & \text { Burrs } \\
\text { - } & \text { Electric } \\
& \text { welding } \\
\text { - } & \text { Ruler }\end{array}$ & 1 \\
\hline 5 & & $\begin{array}{c}\text { Main } \\
\text { Section }\end{array}$ & $\begin{array}{l}\text { Hollow Iron } \\
5 \mathrm{~cm} \times 5 \mathrm{~cm}\end{array}$ & $\begin{array}{ll}\bullet & \text { Cut } \\
- & \text { Weld } \\
- & \text { Clamp }\end{array}$ & 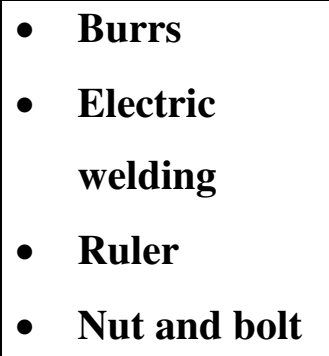 & $\mathbf{1}$ \\
\hline 6 & & Spur Gear & Cast Iron & $\begin{array}{ll}\text { - } & \text { Milling } \\
\text { - } & \text { Lathe } \\
\text { - } & \text { Auger }\end{array}$ & \begin{tabular}{|ll} 
- & Milling \\
& machine \\
- & Lathe \\
- & Sit Drill
\end{tabular} & 1 \\
\hline 7 & 2000 韭 & Gear Rack & Cast Iron & $\begin{array}{ll}\text { - } & \text { Cast } \\
\text { - } & \text { Milling }\end{array}$ & Milling machine & 1 \\
\hline 8 & & Wheel & $\begin{array}{c}\text { Cast Iron } \\
\text { and Rubber }\end{array}$ & Cast & Molding & 4 \\
\hline
\end{tabular}

\section{DISCUSSION}

Using this tool can save time in installing the ceiling compared to installing the ceiling manually or without tools. Its use is very easy so it can reduce labor. This ceiling installation tool is designed to be as simple as possible so that the materials used 
do not require expensive costs and are also easy to operate. This ceiling installation tool can be dismantled to make it easier for users to move to other areas that have narrow road access by moving parts and assembling them again. This tool has a main pole with a size of 1.7 meters that can be adjusted and can move up and down. This up and down movement requires gears and rack gear attached to the main support pole which changes the rotary motion to a straight or up and down motion. For the ceiling section it has a size of 1 meter attached to the top end of the support pole and can extend up to 2 meters so that it can used in several types of ceiling sizes.

In planning this tool using hollow iron with a size of $5 \times 5 \mathrm{~cm}$ and $4 \times 4 \mathrm{~cm}$ with the same thickness of $2 \mathrm{~mm}$, for iron pipes using a size of 1 inch or $2.54 \mathrm{~cm}$ which is used to make stairs. So that the overall weight of the tool material is $51.62 \mathrm{~kg}$ and added to the weight of the user of the tool and the weight of the ceiling size of $1 \mathrm{~m} 2$ with a total of 11 pieces is $178.92 \mathrm{~kg}$. For the material used in the main section using chrome steel JIS G 4140 symbol SCR 3 with a Permit Stress of $90 \mathrm{~kg} / \mathrm{cm}^{2}$, the maximum bending moment is $12798.5 \mathrm{~kg} . \mathrm{cm}$ and the stress that occurs in the main section is $89.09 \mathrm{~kg} / \mathrm{cm}^{2}$ so that This tool is safe to use because the working voltage that occurs is smaller than the allowable voltage. In the planning of this tool, two types of connections are used, namely bolts and welds. For bolt nut connections using a bolt with code M10 with a diameter of $10 \mathrm{~mm}$ and the number of threads 46.6, the tensile stress is 0.3814 $\mathrm{kg} / \mathrm{mm}^{2}$ and for the contact pressure on the threaded surface of $0.00723 \mathrm{~kg} / \mathrm{mm}^{2}$. In the weld joint the tensile stress is $6.92 \mathrm{~kg} / \mathrm{cm}^{2}$, the area of the weld is $17.67 \mathrm{~cm}^{2}$, and has a tensile load of $122.141 \mathrm{~kg}$

\section{CONCLUSION}

According to the results of the planning for the ceiling installation tool above, the following conclusions can be drawn:

- The design of ceiling installation aids can save time and energy efficiency because the tools are easy to assemble and move easily, so that they can reach the room or access to the smallest room.

- The materials needed for the design of a ceiling mount aid are: hollow iron, iron pipes, bolts, gears and rack teeth. This material is relatively easy to find.

- The stress that occurs in the crosssectional area is smaller than the allowable stress so that the planning of this tool is safe.

\section{REFERENCES}

Chandra, D., Gunawan dan M. Fadli."Analisa Tegangan Baut Pengunci Girth-Gear Kiln", Jurnal Teknika Unand - No. 33 Vol. 1 thn XVII.ISNN : 08548471,2010

Jamaludin, P, 2017, “Pengaruh Sudut Kerja Pengelasan Terhadap Kekuatan Las Pada Link Engine Hanger Tipe K16”, Jurnal Teknik Mesin, Universitas Muhammadiyah Tangerang

Spott, M.F,1998, "DesignMachine Elements", Eighth Edition.New Jersey :PearsonPranticeHall 
Sandi Yusuf Heri Wibowo, Darto, I Made Sunada (2019), TRANSMISI, Vol-15 No.1/ p. 393-399

Sularso dan Kiyokatsu Suga. 2004, "Dasar Perancangandan Pemilihan Elemen Mesin", Edisi kedelapan, PT. Pradnya Paramita, Jakarta

Yudya, S., Rokhim dan H. Yudho."Analisa Tekuk Kritis Pada Pipa Berbentuk Segi Empat Yang Dikenai Beban
Bending Dengan Variasi Penampang Horizontal", Teknik Perkapalan, Diponegoro

http://academia.edu/1 1497283/CaraHitung-Berat-Hollow.html 